\title{
Twenty-year-old African American woman with prion disease associated with the G114V PRNP variant
}

Jason Margolesky, MD, and Mario Saporta, MD, PhD

Neurol Genet 2018;4:e229. doi:10.1212/NXG.0000000000000229

\author{
Correspondence \\ Dr. Margolesky \\ jhmargolesky@med.miami.edu
}

The c.341G>T (p.G114V) variant of the prion protein gene (PRNP) has been reported in a Uruguayan and a Chinese family to cause an inheritable prion disease, albeit with incomplete penetrance. The condition is characterized by early-onset, relatively prolonged course, early neuropsychiatric symptoms, followed by pyramidal and extrapyramidal symptoms. We present a 20-year-old African American woman, with no family history of neurodegenerative disease, who presented with rapidly progressive cognitive decline and subsequent movement disorders who was found to have the PRNP variant.

\section{Case report}

A 20-year-old African American woman presented with a history of truncus arteriosus (surgically corrected early in life), and years later, she required a porcine pulmonary valve replacement. Her mother and father, ages 51 and 49, respectively, are alive and well. Her brother is 23 years old and has no medical issues. Her maternal and paternal grandparents reached their ninth decades of life without neurodegenerative disease. She presented to the clinic with involuntary movements. In the months prior, she had developed cognitive decline leading to her failing classes in college. On examination, she was found to have a paucity of spontaneous speech output and bradyphrenia and had an incongruent smiling facial expression. Facial myoclonic jerks were noted as was asymmetric action and postural tremor (affecting her left more than her right arm). Her gait was slow, and she had decreased arm swing bilaterally. She was admitted to the hospital for evaluation of reversible causes of rapidly progressive dementia and prion disease.

Electroencephalography revealed diffuse delta frequency slowing without epileptiform activity. Lumbar puncture and CSF analysis showed no inflammatory cells, normal glucose, and elevated protein levels. Autoimmune and paraneoplastic encephalopathy workup was unremarkable. An empiric course of pulse IV methylprednisolone was tried with no notable improvement. Brain MRI (figure, A and B) demonstrated findings typical of prion disease. CSF and blood samples were sent to the Case Western Prion Lab for analysis where the c.341G $>$ T (p.G114V) variant of the PRNP gene was detected.

One month later, in the clinic, the patient was noted to have more diffuse myoclonic jerks, now involving the extremities as well as her face. Another month passed, and the patient began falling and developed a more cautious gait. She developed emotional lability and would spontaneously cry alternating with irritability. It is interesting to note that such lability (including the inappropriate euphoria described early in her disease course) had been noted in Kuru, leading to the euphemisms "laughing disease" or "laughing death." Clonazepam was started to help with myoclonus, anxiety, and irritability. 
Figure MRI of the brain with findings typical of prion disease
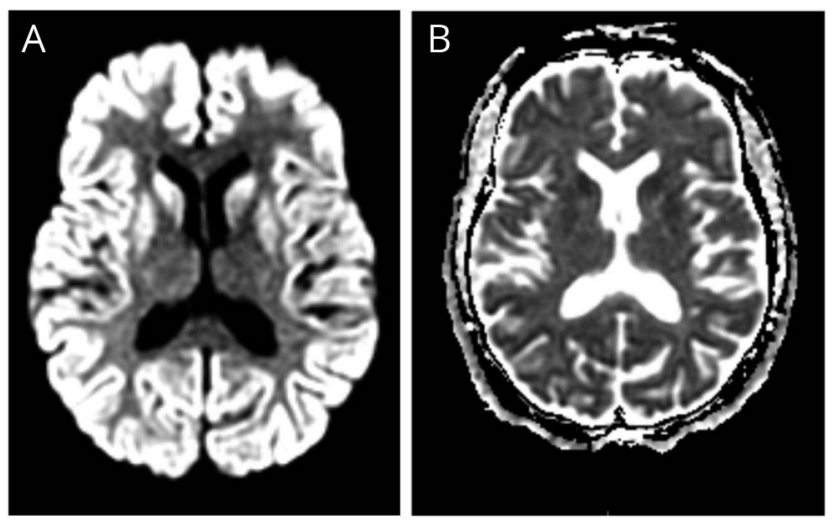

Diffusion weighted imaging (A) and apparent diffusion coefficient (B) MRI brain sequences showing abnormal signal in the cortex diffusely and striatum bilaterally.

\section{Discussion}

The inherited prion diseases, including familial Creutzfeldt-Jakob Disease (CJD), Gerstmann-Sträussler-Scheinker syndrome, and fatal familial insomnia, are autosomal dominant in inheritance and are attributable to mutations in the PRNP gene. The c.341G $>\mathrm{T}$ (p.G114V) PRNP variant was initially reported in members of a Uruguayan family in $2005 .{ }^{2}$ In 2008 , the same variant was reported in a Chinese family.

In the Uruguayan cohort, 4 family members carried the variant and manifested the disease, and 2 family members carried the variant without neurologic signs. Age at onset ranged from 18 to 27 years, and the disease duration ranged from 1 to 4 years. The disease presented with neuropsychiatric disturbances, followed by dementia, parkinsonism, pyramidal signs, myoclonus, and cerebellar signs. In the Chinese cohort, 15 family members were found to carry a heterozygous $\mathrm{G} 114 \mathrm{~V}$ mutation with 4 affected individuals. The age at onset ranged from 32 to 47 years, with a disease duration of $2-3$ years. The clinical presentation was similar to that of the Uruguayan cohort.

Our patient is an African American woman with inherited CJD found to have the rarely reported c.341G $>\mathrm{T}$ (p.G114V) $P R N P$ variant. This finding strengthens the evidence that this variant is pathogenic in causing CJD and expands the possible ethnic backgrounds where this variant may be found. Without genetic information from the patient's parents, we cannot determine whether this represents a sporadic mutation or whether this provides further evidence for the incomplete penetrance of the variant. A high index of suspicion should be held for a diagnosis of CJD in a patient with rapidly progressive dementia, even in a young adult patient.

\section{Author contributions}

Jason Margolesky: conceptualized and wrote the initial draft of the manuscript. Mario Saporta: conceptualized the manuscript and provided critical review of the manuscript.

\section{Study funding}

No targeted funding reported.

\section{Disclosure}

Jason Margolesky reports no disclosures. Mario Saporta has served on the scientific advisory boards of and received research support from the Charcot-Marie-Tooth Association and Acceleron; has served on the editorial board of Journal of the Peripheral Nervous System; and has served as a consultant for Alnylam, Strongbridge, and Biogen. Full disclosure form information provided by the authors is available with the full text of this article at Neurology.org/NG.

Received November 29, 2017. Accepted in final form February 21, 2018.

\section{References}

1. Liperski P, Sikorska B, Lindenbaum S, et al. Kuru: genes, cannibals, and neuropathology. J Neuropathol Exp Neurol 2012;71:92-103.

2. Rodruguez MM, Peoc'h K, Haik S, et al. A novel mutation (G114V) in the prion protein gene in a family with inherited prion disease. Neurology 2005;8:1455-1457.

3. Ye J, Han J, Shi Q, et al. Human prion disease with a G114V mutation and epidemiological studies in a Chinese family: a case series. J Med Case Rep 2008;2:331-336.

4. Liu Z, Jia L, Piao Y, et al. Creutzfeldt-Jakob disease with PRNP G114V mutation in a Chinese family. Acta Neurol Scand 2010;2009:377-383. 


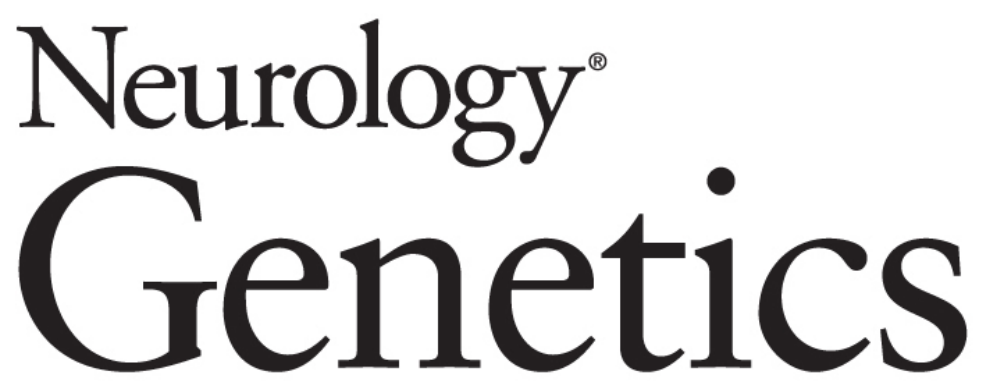

Twenty-year-old African American woman with prion disease associated with the G114V PRNP variant

Jason Margolesky and Mario Saporta Neurol Genet 2018;4;

DOI 10.1212/NXG.0000000000000229

This information is current as of March 22, 2018

Neurol Genet is an official journal of the American Academy of Neurology. Published since April 2015, it is an open-access, online-only, continuous publication journal. Copyright Copyright ( 2018 The Author(s). Published by Wolters Kluwer Health, Inc. on behalf of the American Academy of Neurology. All rights reserved. Online ISSN: 2376-7839.

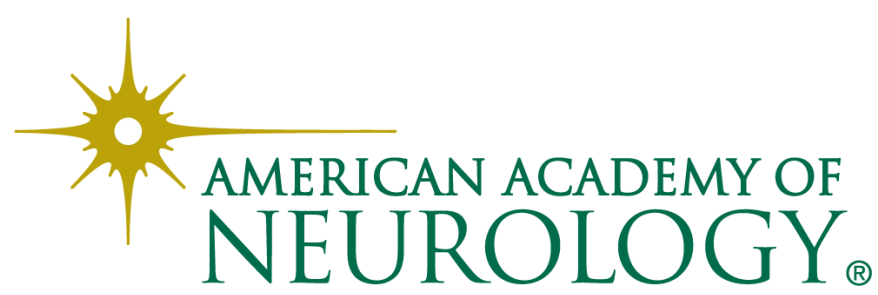




\section{Updated Information \& Services}

References

Subspecialty Collections

Permissions \& Licensing

\section{Reprints}

including high resolution figures, can be found at:

http://ng.neurology.org/content/4/2/e229.full.html

This article cites 4 articles, 0 of which you can access for free at: http://ng.neurology.org/content/4/2/e229. full.html\#\#ref-list-1

This article, along with others on similar topics, appears in the following collection(s):

All Clinical Neurology

http://ng.neurology.org//cgi/collection/all_clinical_neurology

\section{All Genetics}

http://ng.neurology.org//cgi/collection/all_genetics

All Movement Disorders

http://ng.neurology.org//cgi/collection/all_movement_disorders

Myoclonus

http://ng.neurology.org//cgi/collection/myoclonus

Prion disease; see Infections/prion

http://ng.neurology.org//cgi/collection/prion_disease

Information about reproducing this article in parts (figures,tables) or in its entirety can be found online at:

http://ng.neurology.org/misc/about.xhtml\#permissions

Information about ordering reprints can be found online:

http://ng.neurology.org/misc/addir.xhtml\#reprintsus

Neurol Genet is an official journal of the American Academy of Neurology. Published since April 2015, it is an open-access, online-only, continuous publication journal. Copyright Copyright @ 2018 The Author(s). Published by Wolters Kluwer Health, Inc. on behalf of the American Academy of Neurology. All rights reserved. Online ISSN: 2376-7839.

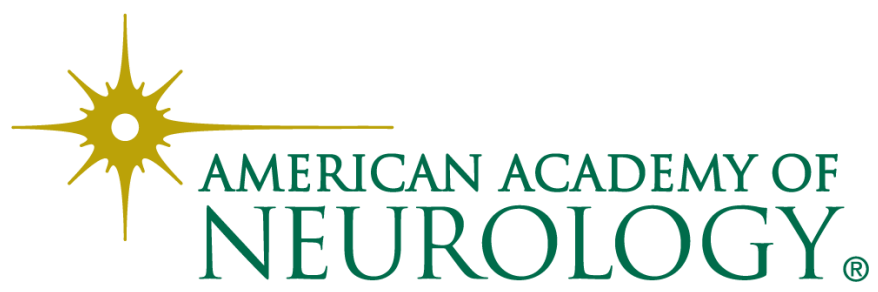

